This chapter to be published as:

Ruse, Michael (2009). “The Biological Sciences Can Act as a Ground for Ethics” in Ayala, Francisco and Arp, Robert, Contemporary Debates in Philosophy of Biology. Oxford: Wiley-Blackwell.

\title{
The Biological Sciences Can Act as a Ground for Ethics
}

Michael Ruse

Ethics is an illusion put in place by natural selection to make us good cooperators.

- Michael Ruse and Edward O. Wilson (1985)

This paper is interested in the relationship between evolutionary thinking and moral behavior and commitments, ethics. There is a traditional way of forging or conceiving of the relationship. This is traditional evolutionary ethics, known as Social Darwinism. Many think that this position is morally pernicious, a redescription of the worst aspects of modern, laissez-faire capitalism in fancy biological language. It is argued that, in fact, there is much more to be said for Social Darwinism than many think. In respects, it could be and was an enlightened position to take; but it flounders on the matter of justification. Universally, the appeal is to progress - evolution is progressive and, hence, morally we should aid its success. I argue, however, that this progressive nature of evolution is far from obvious and, hence, traditional social Darwinism fails. There is another way to do things. This is to argue that the search for justification is mistaken. Ethics just is. It is an adaptation for humans living socially and has exactly the same status as other adaptations, like hands and teeth and genitalia. As such, ethics is something with no standing beyond what it is. However, if we

all thought that this was so, we would stop being moral. So part of the experience of ethics is that it is more than it is. We think that it has an objective referent. In short, ethics is an illusion put in place by our genes to make us good social cooperators.

\section{Introduction}

Not so long ago, evolutionary ethics was the philosophical equivalent of a bad smell. One knew that not only was it false, but somehow it was unclean - it was 
the sign that one had a tin ear for philosophy. First Henry Sidgwick (1874), and then G.E. Moore (1903, in Principia Ethica), had shown that evolutionary ethics simply will not work; in Moore's language, it ignores or ploughs through the naturalistic fallacy. Or, to put matters in a more historical context, evolutionary ethics violates the distinction drawn by David Hume (1978) between is and ought. There are still those today who feel much as these earlier thinkers did. Richard Rorty, in perhaps the last thing he wrote before he died, was severely critical of an attempt by the Harvard evolutionary psychologist Marc Hauser who wants to tie in ethics with our evolutionary past. Rorty (2006) wrote:

We need, Hauser says, a "radical rethinking of our ideas on morality, which is based on the analogy to language.” But the analogy seems fragile. [Noam] Chomsky has argued, powerfully if not conclusively, that simple trial-and-error imitation of adult speakers cannot explain the speed and confidence with which children learn to talk: some special, dedicated mechanism must be at work. But is a parallel argument available to Hauser? For one thing, moral codes are not assimilated with any special rapidity. For another, the grammaticality of a sentence is rarely a matter of doubt or controversy, whereas moral dilemmas pull us in opposite directions and leave us uncertain. (Is it O.K. to kill a perfectly healthy but morally despicable person if her harvested organs would save the lives of five admirable people who need transplants? Ten people? Dozens?) 
Hauser hopes that his book will convince us that "morality is grounded in our biology.” Once we have grasped this fact, he thinks, “inquiry into our moral nature will no longer be the proprietary province of the humanities and social sciences, but a shared journey with the natural sciences." But by "grounded in" he does not mean that facts about what is right and wrong can be inferred from facts about neurons. The "grounding” relation in question is not like that between axioms and theorems. It is more like the relation between your computer's hardware and the programs you run on it. If your hardware were of the wrong sort, or if it got damaged, you could not run some of those programs.

Knowing more details about how the diodes in your computer are laid out may, in some cases, help you decide what software to buy. But now imagine that we are debating the merits of a proposed change in what we tell our kids about right and wrong. The neurobiologists intervene, explaining that the novel moral code will not compute. We have, they tell us, run up against hard-wired limits: our neural layout permits us to formulate and commend the proposed change, but makes it impossible for us to adopt it. Surely our reaction to such an intervention would be, "You might be right, but let's try adopting it and see what happens; maybe our brains are a bit more flexible than you think.” It is hard to imagine our taking the biologists' word as final on such matters, for that would amount 
to giving them a veto over utopian moral initiatives. (pp. 1-2)

Rorty allows that it may be possible "to update our moral software," but he doubts that biology is going to help any time soon.

My sense is that, thanks to evolution, we can do much more than Rorty thought possible. Perhaps the biologists should take things over. Can the biological sciences act as a ground for ethics? I give an emphatic “yes” to this question. Let us see how the case might be made.

\section{Normative Ethics}

In dealing philosophically with morality, there are always two levels to be discussed: normative or substantive ethics, which deals with what one ought to do ("love your neighbor as yourself"), and metaethics which deals with why one ought to do what one ought to do ("God wants you to love your neighbor as yourself”). If one is trying to link evolution and normative ethics, then most obviously one will be trying to show that human ethical relationships are produced by evolution. Clearly, by its very nature, this is a naturalistic process, so let me stress now that my concern in this essay is with methodological naturalism - that is, trying to explain things scientifically - which I take it precludes super-natural events. Things must occur according to unbroken law. Miracles or interventions by the deity (or an Intelligent Designer) are just not allowed. I am saying nothing at all about metaphysical naturalism - whether science is the only thing that there is, or whether there is a world of God beyond 
science. At the end of this chapter, I will have a few things to say about God and metaphysical realities beyond science; but, nothing for now.

In substantive ethics, one is trying to show how people feel about moral statements. One is not judging the moral statements as such, although such an approach does not preclude any argumentation whatsoever about content. One could get into discussion about such issues as consistency, as well as the relevance of factual claims to moral issues. For instance, one might ask whether one is consistent in opposing capital punishment yet, at the same time, allowing abortion on request. One might ask whether peace is more likely if one goes to war with Iran or if one tries other methods of containment. But, ultimately, I take it that one is in the business of description and scientific explanation. (More in a moment on this whole business of arguing for consistency. I agree with those people who think that this issue might be more complex than it looks, and that biology might have something to say on the issue.)

There has been much work done in the past thirty years trying to show how Darwinism does explain (in the sense of showing the origins of) normative ethics (e.g., Sober \& Wilson, 1997; Wright, 1994; Gibbard, 1990; Skyrms, 1998). Although it is a dirty word in philosophical circles, the key breakthrough was the rise of sociobiology in the 1970s, with the various models of kin selection, reciprocal altruism, and the like, showing how Darwinian advantage could be gained by helping others; all a kind of enlightened self-interest on the part of the 
genes (Ruse, 1985, 1986). “You scratch my back and I’ll scratch yours.” Uncomfortable with the "selfish-gene” approach, in recent years a number of holistic-type thinkers have been trying to promote an understanding of selection that emphasizes adaptations for the group (as against adaptations for the individual). I myself am not very keen on this way of seeing things, but here I will not dispute it. The main point is one of overlap. All are attempting to explain normative ethics as the result of evolutionary processes, and by this is meant that natural selection of some kind is the chief causal force. The late Stephen Jay Gould (2002) argued that perhaps mental attributes - and these would presumably include mental moral attributes - simply are what he called spandrels: by-products of the evolutionary process without any adaptive value. Although there are certainly philosophers who would be sympathetic to Gould's approach, the people who have tried to understand ethics in terms of evolution would all dispute this.

For at least two decades, I have been arguing for such a naturalistic, evolution-based approach to normative ethics (Ruse, 1986, 1996, 2001). Here, I do not intend to retread that material. Frankly, I think there is only so far that a philosopher like myself can take the discussion. I stand opposed to Rorty. A naturalistic approach means just that - one puts oneself in the hands of the scientists. These would include primatologists, students of comparative cultures, game theorists, evolutionary psychologists, economists perhaps, and others. All I 
will say here is that I find the results thus far very encouraging, although I am sure my critics would say that they would hardly expect me to find otherwise. I hope people will not be disappointed if I stress that I do not expect to find much difference between the findings of the biologists and the findings of the philosophers. Why should we? We love our neighbors as ourselves because, paradoxically, it is in our interests to do so. That is all there is to be said. That is how we feel.

If authority is needed to bolster my position, let me mention that the great social philosopher, John Rawls (1971), seemed to think that this is how things work. As is well known, his theory of justice as fairness is a form of social contract theory. How would we want society constituted - pay, medical care, and so forth - if we did not know (we were "behind the veil of ignorance”) what role would be allotted to us? We could be female, born of rich parents, healthy, and beautiful; or male, born of poor parents, sick, and ugly. Rawls argues that we want society set up so whatever place we find ourselves in, we would benefit the most given the risks. We cannot just go for the female role because we might end up with the male role. Hence, we want a society that will look after the male as well as possible. This does not necessarily mean that everyone will get the same. If we want good medical care, we might have to pay doctors twice the amount we pay professors. Rather, we want a society where the loser in birth's gamble gets as good a deal as possible. 
Rawls (1971) admits fully that this all talks about hypotheticals. No one thinks that societies were set up by a gang of leaders and then the rules made mandatory. However, perhaps our genes did what our ancestors did not. In arguing for the greater stability of the principles of justice I have assumed that certain psychological laws are true, or approximately so. I shall not pursue the question of stability beyond this point. We may note however that one may ask how it is that human beings have acquired a nature described by these psychological principles. The theory of evolution would suggest that it is the outcome of natural selection; the capacity for a sense of justice and the moral feelings is an adaptation of mankind to its place in nature. As ethologists maintain, the behavior patterns of a species, and the psychological mechanisms of their acquisition, are just as much its characteristics as are the distinctive features of its bodily structures; and these patterns of behavior have an evolution exactly as organs and bones do. It seems clear that for members of a species which live in stable social groups, the ability to comply with fair cooperative arrangements and to develop the sentiments necessary to support them is highly advantageous, especially when individuals have a long life and are dependent on one another. These conditions guarantee innumerable occasions when mutual justice consistently adhered to is beneficial to all parties. (p. 440; in support of his position, Rawls footnotes 
Trivers on reciprocal altruism)

Incidentally, I am fully aware of the fact that biology and philosophy overlap at this point is in major part a function of the fact that they both stem from the same $18^{\text {th }}$ century ideas about competition, working together, and so forth. Darwin drew heavily on Thomas Robert Malthus, as well as Adam Smith and other great thinkers from the Scottish Enlightenment (Ruse, 1999). But I don't think we have a vicious circle here. If the philosophical and economic arguments did not work in biology, we would soon know. I see more of a kind of reinforcing feed-back situation.

\section{Biology Making the Decisions}

Does the biology make no difference to the normative claims? Was Rorty worrying about a pseudo-question when he feared that biologists might make the moral decisions for us? I think biology can sometimes clarify things for us. Take the question of moral obligations to our closest loved ones (spouses, children, friends), as opposed to our moral obligations to total strangers. Some systems perhaps utilitarianism, perhaps Christianity - suggest that the moral obligation lies equally with relative and with stranger. If, with the same amount of effort, you make the stranger happier than your own child - you can feed ten Africans for the price of one North American child - then that is the way you should go. Others, however, suggest that truly charity begins at home:

“You find me, my dears,” said Mrs. Jellyby, snuffing the two great office 
candles in tin candlesticks, which made the room taste strongly of hot tallow (the fire had gone out, and there was nothing in the grate but ashes, a bundle of wood, and a poker), “you find me, my dears, as usual, very busy; but that you will excuse. The African project at present employs my whole time. It involves me in correspondence with public bodies and with private individuals anxious for the welfare of their species all over the country. I am happy to say it is advancing. We hope by this time next year to have from a hundred and fifty to two hundred healthy families cultivating coffee and educating the natives of Borrioboola-Gha, on the left bank of the Niger.” (p. 53)

This is from the great novel by Charles Dickens (2003), Bleak House, where he is highly critical of those who, like Mrs. Jellyby and her concern for the natives of Africa, neglect the sick and poor of their own land (Jo, the crossing sweeper), and even their own families (her children, Caddy and Peepy, for a start). David Hume (1978) had similar sentiments: “A man naturally loves his children better than his nephews, his nephews better than his cousins, his cousins better than strangers, where every thing else is equal. Hence arise our companion measures of duty, in preferring one to the other. Our sense of duty always follows the common and natural course of our passions” (pp. 483-484). All of this fits in very well with our biology, whereas helping strangers at the expense of family does not.

I am not sure that this is a case where biology would change our minds 
about moral thinking, but one might want to say that it helps to clarify difficult situations. It would help us to understand what we really think and want, as opposed to what we might think we want. Could biology actually make the decisions for us? Consider the following (precisely a version of that mentioned by Rorty). Suppose you saw a trolley, out of control, going down the track, about to kill five people, and could choose to set the points to send the cart onto a side line and kill just one person. What would you do? You would probably switch the points. Now suppose you are on a bridge about to fall and you can save five of the six other people on the bridge by pushing off the sixth, fat one. Would you sacrifice him? I doubt you would do it. Why? Does evolution throw some light on this paradox, for formally the case is the same in both cases? People like Peter Singer (2005) suspect that our biologically-evolved emotions might be significant here. Some leading brain researchers, to whom he refers, write as follows: We maintain that, from a psychological point of view, the crucial difference between the trolley dilemma and the footbridge dilemma lies in the latter's tendency to engage people's emotions in a way that the former does not. The thought of pushing someone to his death is, we propose, more emotionally salient than the thought of hitting a switch that will cause a trolley to produce similar consequences, and it is this emotional response that accounts for people’s tendency to treat these cases differently. This hypothesis concerning these two cases suggests a more 
general hypothesis concerning moral judgment: Some moral dilemmas (those relevantly similar to the footbridge dilemma) engage emotional processing to a great extent than others (those relevantly similar to the trolley dilemma), and these differences in emotional engagement affect people’s judgments. (Greene, Sommerville, Nystrom, Darley, and Cohen, 2001, p. 2106)

It might, because the trolley situation is something we (that is, our ancestors) have encountered in the past, whereas the bridge situation is not something we have had experience of. At least, it may be that the emotions have been shaped in the past to do what is in our best evolutionary interests, and this leads to the different responses. All of this suggests that rationality is not quite as nice and tidy as the logicians suggest, and that moral sentiments are more complex than philosophers and moralists have thought in the past. Rawls urges us to achieve "reflective equilibrium” - get our moral sentiments in a consistent whole - but Singer argues that this is simply not possible. And biology shows why.

For myself, I am not arguing this point in a definitive fashion, but I am suggesting that it might be a case where Rorty is wrong, and biology might indeed have a role in helping us with moral decisions. Or understanding why we think certain courses of action right and not others. Actually, I want to argue something rather stronger than this, but before I can do so I must turn to the purely philosophical part of the equation about morality, namely that of justification. 
What of Darwinian metaethics?

\section{Metaethics}

There is still some hesitation by philosophers on this one. It is one thing to turn normative ethics over to the empiricists. It is quite another to think that the results of empirical science can truly answer questions that are so fundamentally philosophical - so dear to the hearts of those of us who stand in the tradition of Plato, Aquinas, and Kant. This ambivalence is shown in a recent piece by the well-known philosopher Philip Kitcher (2003). He asks the question: "So what exactly is the relationship between evolutionary theory and ethics?” Then he gives a preliminary answer:

Let's start with a simple answer. There are many different projects relating evolutionary biology to ethics, some of which are perfectly sensible, others flawed. The hyper-Darwinian ambition is to show how our understanding of the history yields new basic moral principles. Somewhat less ambitiously, one might contend that Darwinism supports some distinctive metaethical view, that it shows, for example, that moral judgements cannot have truth-values or that moral knowledge is impossible. Much more modestly, we can see the evolutionary understanding of our species as relevant to the tracing of all aspects of human history, including the history of our morality and social systems. Finally, one might suppose that recognition of the kinship of life, coupled 
with moral principles we already hold, enables us to arrive at new derivative moral judgements — perhaps we come to understand ourselves as having obligations not to treat other animals in particular ways. The simple answer proposes that the first two of these ventures are illegitimate, while the latter two are well grounded. (pp. 411-412) Kitcher argues that this simple answer is three quarters right, only. The second part of the answer may well be false. "What is more problematic - and more interesting - is the claim about the irrelevance of Darwin for metaethics.” All well and good. But do not get too excited. Before he is finished, Kitcher escapes making any definite decisions, concealed as he is in a cloud of apparently judicious hesitation about making any final judgments before all the facts are in: In outline, we can view morality as a human phenomenon that enters our history as a device for regulating the conflict between our sympathetic and selfish dispositions (where regulation plays a key role in the maintenance of our societies) and is further articulated through interactions among different social groups and members' reflections on those interactions. What status this assigns to our moral claims depends, I suggest, on the details of the story, and the details require much more research in evolutionary biology, anthropology, psychology and history than anyone has yet attempted. (p. 415)

Positions of this kind are not unknown in the philosophical community. If the 
science turns up trumps, I was there before you. And if not, then don’t blame me. Run with the hare of naturalism, and hunt with the hounds of anti-naturalism and blame science for your ambivalence.

Let me rush in where angels fear to tread. There is another philosophical tradition to ethics - that of Aristotle, Hobbes, and Hume, where the natural world is considered relevant, all the way down (or up). I believe we do now have enough material to make some judgments and decisions at the metaethical level, and in this discussion I am going to show you why I believe this. I agree that we do not have everything in that we would like at the normative level. All of the details - perhaps, even, the broad strokes - of the natural development of morality have not been explicated and explained. But as Kitcher himself agrees in the last quotation just given, we do have something. Biology - let us now agree for the sake of argument, natural selection - has played some significant role in making us moral beings. Morality is an adaptation like hands, teeth, penises, and vaginas. Obviously biology does not play the only role, and we must certainly allow culture some significant part also. How significant we can leave more or less open, between two false extremes - that everything is basically cultural (the blank slate hypothesis) and that everything is basically biological (the genetic determinism hypothesis). The point is that morality has come through human evolution, and it is adaptive.

\section{Social Darwinism}


Thinking now about metaethical issues, there is a traditional way of relating evolution and morality; that is, about issues centering on the justification or foundation of morality. (Why should I do that which I should do?) This is the way of Social Darwinian (Ruse, 1996; Richards, 1987). Take as a paradigm the nineteenth-century philosopher Herbert Spencer. He argued from the way that things have been, to the way that things ought to be. One ferrets out the nature of the evolutionary process - the mechanism or cause of evolution - and then one transfers it to the human realm (if this has not already been done), arguing that which holds as a matter of fact among organisms holds as a matter of obligation among humans (Ruse, 1986). Spencer $(1851,1857)$ himself started with the struggle for existence and the consequent selective effects: a connection which he made years after Darwin made the connection, but years before Darwin published. He then transferred to the human realm: not much to do here, actually, since Spencer speculated on selective effects showing themselves in the different natures and behaviors of the Irish and the Scots. He concluded that struggle and selection in society translates into extreme laissez faire socioeconomics: the state should stay out of the way of people pursuing their own self-interests and should not at all attempt to regulate practices or redress imbalances or unfairnesses. Libertarian license, therefore, is not only the way that things are, but the way that they should be.

In fact, Spencer (1851) was far from convinced that mid-Victorian Britain 
was a laissez faire society, but this is what he hoped fervently it would become. We must call those spurious philanthropists, who, to prevent present misery, would entail greater misery upon future generations. All defenders of a Poor Law must, however, be classed among such. That rigorous necessity which, when allowed to act on them, becomes so sharp a spur to the lazy and so strong a bridle to the random, these pauper's friends would repeal, because of the wailing it here and there produces. Blind to the fact that under the natural order of things, society is constantly excreting its unhealthy, imbecile, slow, vacillating, faithless members, these unthinking, though well-meaning, men advocate an interference which not only stops the purifying process but even increases the vitiation -- absolutely encourages the multiplication of the reckless and incompetent by offering them an unfailing provision, and discourages the multiplication of the competent and provident by heightening the prospective difficulty of maintaining a family. (pp. 323-324) Spencer could sound positively brutal about those who would help the unfortunate within society: "Besides an habitual neglect of the fact that the quality of a society is physically lowered by the artificial preservation of its feeblest members, there is an habitual neglect of the fact that the quality of a society is lowered morally and intellectually, by the artificial preservation of those who are least able to take care of themselves... For if the unworthy are helped to 
increase, by shielding them from that mortality which their unworthiness would naturally entail, the effect is to produce, generation after generation, a greater unworthiness” (Richards, 1987, p. 303).

I should say that not everyone argued in this way from evolution. At times, Social Darwinism reminds one of Christianity. It tells us that we should love our neighbors as ourselves. To President George W. Bush, this translates out as invading Iraq. To the Quakers, it translates out as pacificism. Showing how evolution can serve different ends, take another ardent evolutionary ethicist in the Spencerian tradition, Julian Huxley (the grandson of Thomas Henry Huxley and the older brother of the novelist Aldous Huxley). He argued that evolution justifies an obsession with technology, science, and major public works. While Huxley (1934) was not uninterested in life at the personal level, it was the general domain which really excited him.

All claims that the State has an intrinsically higher value than the individual are false. They turn out, on closer scrutiny, to be rationalizations or myths aimed at securing greater power or privilege for a limited group which controls the machinery of the State. On the other hand the individual is meaningless in isolation, and the possibilities of development and self-realization open to him are conditioned and limited by the nature of the social organization. The individual thus has duties and responsibilities as well as rights and privileges, or if you prefer it, 
finds certain outlets and satisfactions (such as devotion to a cause, or participation in a joint enterprise) only in relation to the type of society in which he lives. (pp. 138-139)

The key moral principle seems to have been for the need of planning in running the state and, above all, the application of scientific principles and results in such planning and its implementation. You simply cannot (or should not) leave things to chance or intuition - the implication being that this is precisely where your average politician does leave things - but should bring the trained scientific mind to bear on life's problems.

Again and again, Huxley returned to this theme. For instance, in a book which he wrote in the inter-war years, If I Were Dictator, he stressed the need for science in the running of an efficient state and that such science would need to be of the social variety as well as physico-chemical and biological. During the Second World War, he wrote a highly laudatory essay on the Tennessee Valley Authority, that marvel of the Rooseveltian New Deal, whereby the federal government built and ran a massive system of river damming and irrigation in what had hitherto been one of the more desolate parts of the U.S. Then, after the War it was Huxley who insisted on the Science being added to UNESCO, and he wrote a vigorous polemic arguing that the organization had to be run on evolutionary lines - lines demanding lots of science. So vigorous was his polemic indeed, that he upset his masters and he was refused a full four-year term as 
director general.

\section{Progress}

But how does one justify moves like those of Spencer and Julian Huxley? It is here that Moore and others found the fallacy. Because things are this way, it does not follow that things should be this way. In fact, I myself agree with this criticism, but my experience is that Social Darwinians (these days, they tend not to be called by this name) find this criticism supremely unimpressive. My sometime co-author Edward O. Wilson points out that, while it is indeed true that one is going from "is" to "ought" - in his own case he is concerned to promote biodiversity, as one does when saving the Brazilian rain forests and, hence, goes from the premise that humans need biodiversity to the conclusion that we should promote biodiversity - this in itself hardly makes the inference fallacious (Wilson 1984, 1992, 1994). In science, one is always going from talk of one kind to talk

of another kind, and no one thinks this fallacious in itself. In gas theory, one goes from talk of molecules bouncing around a chamber at different speeds, to talk of increases in pressure and temperature. Is this any more odd that going from "humans need the forests” to "we ought to preserve the forests”?

We need to dig further into the metaethics of Social Darwinian, and soon the real reason for the confidence becomes apparent. To a person, Social Darwinians - call them traditional evolutionary ethicists, if you prefer - are progressionists. They think that the course of evolution is upwards, from the bad 
or the non-moral to the good and the moral and the worthy of value. Hence, to keep this progress going is in itself a good thing. Listen, for instance, to Herbert Spencer (1857). For him, evolution was a transition from the undifferentiated or what he called the "homogeneous," to the completely mixed up or what he called the heterogeneous. Progress was not just a biological or a social phenomenon: it was an all-encompassing world philosophy.

Now we propose in the first place to show, that this law of organic progress is the law of all progress. Whether it be in the development of the Earth, in the development of Life upon its surface, in the development of Society, of Government, of Manufactures, of Commerce, of Language, Literature, Science, Art, this same evolution of the simple into the complex, through successive differentiations, hold throughout. From the earliest traceable cosmical changes down to the latest results of civilization, we shall find that the transformation of the homogeneous into the heterogeneous, is that in which Progress essentially consists. (p. 35) Likewise with later thinkers of this ilk. It is progress, and the need to keep it going, that is the foundation. Julian Huxley (1927) is quite clear on this:

When we look at evolution as a whole, we find, among the many directions which it has taken, one which is characterized by introducing the evolving world-stuff to progressively higher levels of organization and so to new possibilities of being, action, and 
experience. This direction has culminated in the attainment of a state where the world-stuff (now moulded into human shape) finds that it experiences some of the new possibilities as having value in or for themselves; and further that among these it assigns higher and lower degrees of value, the higher values being those which are more intrinsically or more permanently satisfying, or involve a greater degree of perfection.

The teleologically-minded would say that this trend embodies evolution's purpose. I do not feel that we should use the word purpose save where we know that a conscious aim is involved; but we can say that this is the most desirable direction of evolution, and accordingly that our ethical standards must fit into its dynamic framework. In other words, it is ethically right to aim at whatever will promote the increasingly full realization of increasingly higher values. (p. 137)

Likewise Edward O Wilson (1992): “the overall average across the history of life has moved from the simple and few to the more complex and numerous. During the past billion years, animals as a whole evolved upward in body size, feeding and defensive techniques, brain and behavioral complexity, social organization, and precision of environmental control - in each case farther from the nonliving state than their simpler antecedents did.” He concludes: "Progress, then, is a property of the evolution of life as a whole by almost any 
conceivable intuitive standard, including the acquisition of goals and intentions in the behavior of animals” (p. 187). The point is made.

And here I think is the reason to be dubious about the metaethics of Social Darwinism. Popular though it may be, the very idea of progress in evolution is clouded in problems. It is far from obvious either that natural selection promotes progress or that progress actually occurs, at least in any clear definable and quantifiable way. One can, of course, label humans as the pinnacle of being - I myself am inclined to do just this - but such an act is arbitrary, at least as applied to evolution. Why not label a dog the pinnacle of being or a buttercup? From a biological point of view, the AIDS virus is far more successful than the gorilla, but does anyone truly want to say that the former is superior in a moral or other value sense than the latter?

In a typically hyperbolic fashion, Stephen Jay Gould (1988) writes: “Progress is a noxious, culturally embedded, untestable, nonoperational, intractable idea that must be replaced if we wish to understand the patterns of history” (p. 319). With respect to human evolution, Gould (1989) writes: “Since dinosaurs were not moving toward markedly larger brains, and since such a prospect may lie outside the capabilities of reptilian design... we must assume that consciousness would not have evolved on our planet if a cosmic catastrophe had not claimed the dinosaurs as victims. In an entirely literal sense, we owe our existence, as large and reasoning mammals, to our lucky stars” (p. 318). Even if 
one thinks that this is perhaps a little extreme, there is surely enough truth to make one very wary about biological progress as a basis for one’s moral code.

Whatever one might say about the normative ethics of Social Darwinism - and

although I am not very keen on laissez faire, I am very keen on the rainforests and their preservation; metaethically, the justification seems shaky.

\section{Ethical Skepticism}

But can one do better? Can one overcome Kitcher’s hesitation? I think one can. Remember that, for the sake of argument, we are agreeing - and I think Kitcher gives us this much - that we humans have built-in innately, or instinctively if you like, a capacity for working together socially. And this capacity manifests itself at the physical level as a moral sense. Hence morality or, rather, a moral sense is something which is hard-wired into humans - mediated and fashioned by culture. Morality has been put there by natural selection in order to get us to work together socially or to cooperate. This is not to say that we do not have freedom in any sense. It is not to say that we never disregard our moral sense, but rather that we do have the moral sense and we have the moral sense not by choice or decision, but because we are human. (Of course, there are going to be psychopaths without a moral sense, but in biology you know that there are going to be exceptions for every rule). The claim, therefore, is that when humans find themselves in a position where cooperation might pay, morality kicks into place.

This is not to say that we always will cooperate or be moral. We are 
influenced by many factors, including selfish and other sorts of desires. But morality is one of these factors and, overall, we humans do generally work together. Sometimes the morality backfires. I might go to the aid of drowning child, and drown myself. This is hardly in my self-interest. But, on balance, it is in my interests to have the feeling that I ought to help people in distress, particularly children in distress. This is both because I myself was at some stage of my life a child, and also because I myself will probably have or be having children. I want others to be prepared to make a risk on my behalf or on the behalf of my children.

Let it also be stressed that humans have a genuine sense of morality. It is the kind of morality that someone like Immanuel Kant (1949) talks about. This is not a scientific position of pure ethical egoism in the sense that we are all selfish people just simply calculating for our own ends. We are, rather, people with a real moral sense, a feeling of right and wrong and obligation. Admittedly, at the causal level, this may well be brought about by individual selection maximizing our own reproductive ends. But the point is that, although humans are produced by selfish genes, selfish genes do not necessarily produce selfish people. In fact, selfish people in the literal sense tend to get pushed out of the group or ostracized pretty quickly. They are simply not playing the game. In a way, therefore, we have a kind of social contract. But note that it is not a social contract brought about, in the long-distant past, by a group of grey-bearded, old men sitting around 
a camp fire. It is rather a social contract brought on by our biology, that is to say, by our genes as fashioned and selected by natural selection. Remember Rawls on this point.

This, then, is the Darwinian perspective on the evolution and current nature of morality. Let us now see how this plays out when we try to put things into a philosophical context. What kind of metaethical justification can one give for such claims as that one ought to be kind to children, and that one ought to favor one's own family over those of others? I would argue, paradoxically but truthfully, that ultimately there is no justification which can be given! That is to say, I argue that at some level one is driven to a kind of moral skepticism: a skepticism, please note, about foundations rather than about substantive dictates. What I am saying therefore is that, properly understood, the Darwinian approach to ethics leads one to a kind of moral non-realism (Ruse, 1986).

In this respect, the Darwinian metaethics I am putting forward in this chapter differs very dramatically from traditional Darwinian metaethics, that of Social Darwinism. There, the foundational appeal is to the very fact of evolution. People like Herbert Spencer and Edward O. Wilson argue that one ought to do certain things because by so doing one is promoting the welfare of evolution itself. Specifically, one is promoting human beings as the apotheosis of the evolutionary process - a move we have seen condemned by philosophers as a gross instance of the naturalistic fallacy, or as a flagrant violation of Hume's Law 
(that which denies that one can move legitimately from the way that things are, to the way that things ought to be). My kind of evolutionary metaethics agrees with the philosopher that the naturalistic fallacy is a fallacy and so, also, is the violation of Hume's Law. My kind of evolutionary metaethics also agrees that Social Darwinism is guilty as charged. But my kind of evolutionary metaethics takes this failure as a spring board of strength to its own position. The Darwinian metaethics of this chapter avoids fallacy, not so much by denying that fallacy is a fallacy, but by doing an end run around it, as it were. There is no fallacious appeal to evolution as foundations because there are no foundations to appeal to!

Although I am arguing that morality does exist, if without foundations, do note that my position has a real bite that other positions do not have. Go back to the researchers on psychological reasons for our taking different paths on the trolley versus the bridge situation. They ran experiments that showed that it is truly the case that we use different parts of the brain to make the two different assessments. Emotion is involved and not just some disinterested reason. They conclude:

The trolley and footbridge dilemmas emerged as pieces of a puzzle for moral philosophers: Why is it acceptable to sacrifice one person to save five others in the trolley dilemma but not in the footbridge dilemma? Here we consider these dilemmas as pieces of a psychological puzzle: How do people manage to conclude that it is acceptable to sacrifice one for the 
sake of five in the one case but not the other? We maintain that emotional response is likely to be the crucial difference between these two cases. But this is an answer to the psychological puzzle, not the philosophical one. Our conclusion, therefore, is descriptive rather than prescriptive. We do not claim to have shown any actions or judgments to be morally right or wrong. (Greene et al., 2001, p. 2107)

Actually, they go on to say that the story is a little more complex than this because, in some sense, reason can get involved along with the emotions. But the point I want to make is clear. As a moral skeptic, I argue that there is no higher court of appeal than the emotions. To quote David Hume (1978): "Reason is, and ought only to be, the slave of the passions” (2.3.3.4). This is what right and wrong is all about. At this point the descriptive and prescriptive come together. Not because the former justifies the latter, but because the former leads us causally to have the latter and there is nothing more. (At least, there is nothing more in a naturalistic world. See below for some religious qualifications.) The one decision is right and the other wrong, and that is all there is to it. It is all a bit like baseball. After three outs, your share of the innings is over. That is it. There is no higher appeal. Of course, in baseball you can decide not to play, or to play tennis instead. In life, things are not so easy, and those of us who do try to opt out - like Raskolnikov in Crime and Punishment - tend (if we are not sociopaths) to find ourselves being tugged back in. Our psychology trumps what our reason 
might tell is really what is happening. Hume (1978) again:

The intense view of these manifold contradictions and imperfections in human reason has so wrought upon me, and heated my brain, that I am ready to reject all belief and reasoning, and can look upon no opinion even as more probable or likely than another. Where am I, or what? From what causes do I derive my existence, and to what condition shall I return? Whose favor shall I court, and whose anger must I dread? What beings surround me? and on whom have I any influence, or who have any influence on me? I am confounded with all these questions, and begin to fancy myself in the most deplorable condition imaginable, environed with the deepest darkness, and utterly depraved of the use of every member and faculty. Most fortunately it happens that, since reason is incapable of dispelling these clouds, nature herself suffices to that purpose, and cures me of this philosophical melancholy and delirium, either by relaxing this bent of mind, or by some avocation, and lively impression of my senses, which obliterate all these chimeras. I dine, play a game of backgammon, I converse, and am merry with my friends; and when, after three or four hours amusement, I would return to these speculations, they appear so cold, and strained, and ridiculous, that I cannot find in my heart to enter into them any farther. (p. 269) 


\section{Objectification}

To be blunt, my Darwinianism says that substantive morality is a kind of illusion, put in place by our genes, in order to make us good social cooperators (Ruse \& Wilson, 1985, 1986). I would add that the reason why the illusion is such a successful adaptation is that not only do we believe in substantive morality, but we also believe that substantive morality does have an objective foundation. An important part of the phenomenological experience of substantive ethics is, not just that we feel that we that ought to do the right and proper thing, but that we feel that we ought to do the right and proper thing because it truly is the right and proper thing. As John Mackie (1979) argued before me, an important part of the moral experience is that we objectify our substantive ethics. There are, in fact, no foundations, but we believe that there are in some sense foundations.

There is a good biological reason why we do this. If, with the emotivists, we thought that morality was just simply a question of emotions without any sanction or justification behind them, then pretty quickly morality would collapse into futility. I might dislike you stealing my money, but ultimately why should you not do so? It is just a question of feelings. But in actual fact, the reason why I dislike you stealing my money is not simply because I do not like to see my money go, but because I think that you have done wrong. You really and truly have done wrong in some objective sense. This gives me and others the authority 
to criticize you. Substantive morality stays in place as an effective illusion because we think that it is no illusion but the real thing. Thus, I am arguing that the epistemological foundation of evolutionary ethics is a kind of moral nonrealism, but that it is an important part of evolutionary ethics that we think it is a kind of moral realism.

This is my counter to the worries expressed by people like Alex Rosenberg (2003), who point out that the kind of position that I endorse is close to the twentieth-century, moral philosophy of emotivism - where ethical claims are simply emotive utterances - and who point out, also, that emotivism is clearly false. Killing babies is wrong is not just an emotive cry, but a claim about something's being truly really wrong. For me, substantive ethics is only emotion, but it means more than that. Ethics is subjective, but its meaning is objective.

\section{Spiritualism}

In a way, what has been given thus far is just a statement rather than a proof. What justification can I offer for my claim that evolution points towards ethical skepticism (about foundations)? Why should one not say that there truly is a moral reality underlying morality at the substantive level, and that our biology has led us to it? After all we would surely want to say that we are aware of the speeding train bearing down on us because of our biology, but this in no sense denies the reality of the speeding train (Nozick, 1981). Why should we not say, in a like fashion, that we are aware of right and wrong because ultimately there is an 
objective right and wrong lying behind moral intuitions?

However, things are rather different in the moral case from the speedingtrain case. A more insightful analogy can be drawn from spiritualism. In the First World War, when so many young men were killed, the bereaved - the parents, the wives, the sweethearts, on both sides of the trenches - often went to spiritualists, hoping to get back in touch with the departed dead. And indeed they would get back in touch. They would hear the messages come through the Ouija boards or whatever assuring them of the happiness of the now deceased. Hence, the people who went to spiritualists would go away comforted. Now, how do we explain this sort of thing? Cases of fraud aside, we would say that people were not listening to the late departed, but rather were hearing voices created by their own imaginations which were, in some sense, helping them to compensate for their loss. What we have here is some kind of individual illusion brought about by powerful social circumstances. No one would think that the late Private Higgins was really speaking to his mum and dad. Indeed, there are notorious cases where people were reported killed and then found not to be dead. How embarrassing it would be to have heard the late departed assure you of his well being, and then to find out that the late departed was in fact lying injured in a military field hospital.

In the spiritualism case, once we have got the causal explanation as to why people hear as they do, we recognize that there is no further call for ultimate foundations. I would argue that the biological case is very similar. That there are 
strong biological reasons for cooperation; naturally, we are going to be selfish people but as cooperators we need some way to break through this selfishness; and so our biology has given us morality in order to help us do it. Once again, I stress that this is not to say that we are always going to be moral people; in fact, we are an ambivalent mixture of good and bad, as the Christian well knows (Ruse, 2001). It is to say that we do have genuine moral sentiments which we think are objective, and that these were put in place by biology. Once we recognize this, we see the sentiments as illusory - although, because we objectify, it is very difficult to recognize this fact. That is why I am fairly confident that my having told you of this fact will not now mean that you will go off and rape and pillage, because you now know that there is no objective morality. The truth does not always set you free.

\section{Progress Again}

But, still, you might protest that this does not mean that there is no objective morality behind all of this: either an objective morality of a Platonic ilk which actually exists out there, or an objective morality of the Kantian form which is a kind of necessary condition for rational beings getting along. Here, however, the Darwinian can come back with a further argument, namely, one based on the doubts expressed earlier about biological progress. There is no natural climb upwards from the blob up to the human, from the monad to the man, as people used to say in the nineteenth century. Rather, evolution is a directionless process, 
going nowhere rather slowly (Ruse, 1993; McShea, 1991). What this means, in this particular context, is that there is really no reason why humans might not have evolved in a very different sort of way, without the kind of moral sentiments that we have. From the Darwinian perspective, there is no ontological compulsion about moral thinking.

It is true that, as Kant stressed, it may possibly be that social animals may necessarily have to have certain formal rules of behavior. But it is not necessarily the case that these formal rules of behavior have to incorporate what we would understand as common-sense (substantive) morality. In particular, we might well have evolved as beings with what I like to call the "John Foster Dulles system of morality,” so named after Eisenhower's secretary of State during the Cold War in the 1950s. Dulles hated the Russians, and he knew that the Russians hated him. He felt he had a moral obligation to hate the Russians because if he did not, everything would come tumbling down. But because there was this mutual dislike, of a real obligation-based kind, there was in fact a level of cooperation and harmony. The world did not break down into war and destruction. As a Darwinian, it is plausible to suggest that humans might have evolved with the John Foster Dulles kind of morality, where the highest ethical calling would not be love your neighbor, but hate your neighbor. But remember that your neighbor hates you and, so, you had better not harm him or her because they are going to come straight back at you and do the same. 
Now, at the very least, this means that we have the possibility not only of our own (substantive) morality but of an alternative, very different kind of morality: a morality which may have the same formal structure, but which certainly has a different content. The question now is, if there is an objective foundation to substantive morality, which of the two is right? At a minimum, we are left with the possibility that we humans now might be behaving in the way that we do but that, in fact, what is objective morality is something quite else from what we believe. We believe what we do because of our biology, and we believe that because of our biology that our substantive morality is objectively justified. But the true objective morality is something other from what we have.

Obviously, this is a sheer contradiction to what most people mean by objective morality. What most people mean by objective morality incorporates the fact that it is going to be self-revealing to human beings. Not necessarily to all human beings but - like Descartes’ clear and distinct ideas - certainly selfrevealing to all decent human beings who work hard at it. So, given Darwinism, we have a refutation of the existence of such a morality. Darwinian evolutionary biology is non-progressive, pointing away from the possibility of our knowing objective morality. We might be completely deceived, and since objective morality could never allow this, it cannot exist. For this reason, I argue strongly that Darwinian evolutionary theory leads one to a moral skepticism, a kind of moral non-realism. 
Remember incidentally, what was stressed at the beginning of this whole discussion: All of my arguments are based on an assumption of naturalism, methodological naturalism (meaning that science can make no appeal to the super-natural) that is. Is my position necessarily atheistic, denying the existence of God or of morality being something that He decrees? In other words, am I also committed to metaphysical naturalism (meaning that there is no super-natural)? I would say not. It is quite open for the believer to take my position and say that this is the way that God creates morality - not by laying down divine laws by fiat, rather like the laws of mathematics, but by making morality emerge from human nature. In fact, of course, my position paves the way perfectly for a natural law theory of morality, where it is precisely the case that morality is a matter of human nature rather than simply dictates from above (Arnhart, 2005; Ruse, 2009). This gets around the problem with crude divine command theories of morality, which are open to questions like: "Could God have made it okay to rape little old ladies, if he had wanted to?” The answer is: “No, not if he created humans as he did. Our human nature dictates that rape is wrong." I would say that here we are close to the Leibnizian solution to physical evil. Pain from burning is part of the overall human design. Likewise, the moral emotions that we have are part of the human design.

I do recognize that, as so often happens, you cannot quite leave things here. You close off one problem and another emerges. I have argued strongly 
against progress, but if one is a Christian then one cannot allow that the appearance of humans - or human like beings, with intelligence and a moral sense - is just contingent. For Christians, humans are part of God's plan. Here I think you need a theological rather than a scientific solution. Don't try to smuggle progress back in. Rather, be Augustinian. God stands outside time. For Him, the thought of creation, the act of creation, and the product of creation are as one. Humans could evolve. We know that because they have! I don’t know how likely it was: In every universe? In one universe in ten? One in a million? Or more? The point is that it does not matter to God, whether he creates a billion universes at once or a billion end on end (Ruse, 2010). Time is irrelevant to him. We would emerge somewhere down the line. And we did! It can be just as contingent a process as Gould insists. In fact, Gould himself has gone so far as to say that he thinks human-like beings might emerge in this universe, even if we had not done so: "I can present a good argument from "evolutionary theory" against the repetition of anything like a human body elsewhere; I cannot extend it to the general proposition that intelligence in some form might pervade the universe” (Dick, 1996, p. 395).

So you don't need progress, but you can get humans and their morality, and that is what the Christian needs. Indeed, if I were a Christian, I would just love the conclusions of this paper.

\section{Conclusion}


This, then, is my counter to folk like Philip Kitcher, and also why I think that the biological sciences can act as a ground for ethics. Should you point out that, far from being very original, my whole position starts to sound very much like that of David Hume, who likewise thought that morality was a matter of psychology rather than reflection of non-natural objective properties, I shall take this as a compliment, not a criticism. It is indeed true that I regard my position as that of David Hume - brought up to date via the science of Charles Darwin. What better mentors could one have than them?!

\section{Postscript: Counterpoint}

\section{Response to Ayala}

In a way, Francisco J. Ayala and I are so close together. In a way, Francisco J. Ayala and I are so far apart!

How are we together? We are both ardently committed Darwinian evolutionists and we both believe absolutely and completely that humans are part of this picture. God does not come into it. This does not mean that God does or does not exist. Whatever our personal religious beliefs, Ayala and I respect the integrity of someone who does believe. What it means is that God plays no direct role in the making of humans. It may be His process, but it is a process and not a direct miracle. Again we are together in thinking that morality, ethics, can and must be given a naturalistic explanation. For us, there is no climbing up the mountain and getting the truth on tablets of stone. And finally we are together in 
thinking that morality is a product of our evolutionarily acquired abilities. We are both evolutionary ethicists.

How are we apart? I want to make morality a direct product of biology, something that came about directly because of natural selection. It is, in the language of the biologists, an adaptation. It is an adaptation like hands and teeth and penises and vaginas. Or rather it is a social adaptation like the pheromone trails that the leaf-cutter ants leave to guide their nest mates to the bounty. No less, but certainly no more. (Lots more, actually, but still in the world of adaptation.) Ayala wants to make it all indirect. In the language of the biologists, morality is an exaptation. Morality is not akin to reciprocal altruism or kin selection (or the products thereof) but is something brought about by intelligence (which is a selection-produced adaptation) and hence in the realm of culture and not biology. In other words, morality comes only on the back of real adaptations, and of course might not be or might be quite otherwise.

I see humans (with respect to morality) as absolutely and completely part of the animal world. Ayala sees humans (with respect to morality) as transcending the animal world. It would be easy to sneer and say that this is just what you might expect from a former Catholic priest. But I am not sure that the connection holds. Why am I, a formerly very intense Quaker, not inclined like him? It is probably better to leave the psychology out of it. In any case, I don't think that my position is any less religious than his, meaning that if one were a 
Christian and wanted to say that God stands behind everything. I don't see why God should not stand behind my position rather than Ayala's. But that perhaps is a topic for another discussion. For now, let me say that I am fascinated by our differences and I hope our readers are, too.

\section{References}

Arnhart, L. (2005). Darwinian conservativism. New York: Imprint Academic.

Dick, S. (1996). The biological universe: The twentieth-century extraterrestrial life debate and the limits of science. Cambridge: Cambridge University Press.

Dickens, C. (2003). Bleak house. New York: Penguin Classics.

Gibbard, A. (1990). Wise choices, apt feelings: A theory of normative judgment. Cambridge, MA: Harvard University Press.

Gould, S. (1988). On replacing the idea of progress with an operational notion of directionality. In M. Nitecki, (Ed.), Evolutionary progress (pp. 319-338). Chicago: The University of Chicago Press.

Gould, S. (1989). Wonderful life: The Burgess Shale and the nature of history. New York: W.W. Norton.

Gould, S. (2002). The structure of evolutionary theory. Cambridge, MA: Harvard University Press.

Greene, J., Sommerville, R., Nystrom, L., Darley, J., and Cohen, J. (2001). An fRMI investigation of emotional engagement in moral judgment. Science, 
293, 2105-2108.

Hauser, M. (2006). Moral minds: How nature shaped our universal sense of right and wrong. New York: Ecco Publishers.

Hume, D. (1978). A treatise of human nature. Oxford: Oxford University Press.

Huxley, J. (1927). Religion without revelation. London: Ernest Benn.

Huxley, J. (1934). If I were dictator. New York: Harper and Brothers.

Huxley, J. (1943). TVA: Adventure in planning. London: Scientific Book Club.

Huxley, J. (1948). UNESCO: Its purpose and its philosophy. Washington, DC: Public Affairs Press.

Kant, I. (1949). Critique of Practical Reason. Chicago: University of Chicago Press.

Kitcher, P. (2003). In Mendel's mirror: Philosophical reflections on biology. New York: Oxford University Press.

Mackie, J. (1979). Hume's moral theory. London: Routledge and Kegan Paul.

McShea, D. (1991). Complexity and evolution: What everybody knows. Biology and Philosophy, 6, 303-325.

Moore, G. (1903). Principia ethica. Cambridge: Cambridge University Press.

Nozick, R. (1981). Philosophical explanations. Cambridge, MA: Harvard University Press.

Rawls, J. (1971). A theory of justice. Cambridge, MA: Harvard University Press. Richards, R (1987). Darwin and the emergence of evolutionary theories of mind 
and behavior. Chicago: University of Chicago Press.

Rorty, R. (2006, 27 August). Born to be good: A book review of Moral Minds, by Marc Hauser. New York Times, sec. Book Reviews. Available at: http:// www.nytimes.com/2006/08/27/books/review/Rorty.t.html?_r=1\&fta=y\&o ref=slogin.

Rosenberg, A. (2003). Darwinism in moral philosophy and social theory. In M. Hodge \& G. Raddick (Eds.), The Cambridge companion to Darwin (pp. 310-332). Cambridge: Cambridge University Press.

Ruse, M. (1985). Sociobiology: Sense or nonsense? Dordrecht: Reidel.

Ruse, M. (1986). Taking Darwin seriously: A naturalistic approach to philosophy. Oxford: Blackwell.

Ruse, M. (1993). Evolution and progress. Trends in Ecology and Evolution, 8, 5559.

Ruse, M. (1996). Monad to man: The concept of progress in evolutionary biology. Cambridge, MA: Harvard University Press.

Ruse, M. (1999). The Darwinian revolution: Science red in tooth and claw. Chicago: University of Chicago Press.

Ruse, M. (2001). Can a Darwinian be a Christian? The relationship between science and religion. Cambridge: Cambridge University Press.

Ruse, M., Ed. (2009). Darwin and philosophy. Princeton: Princeton University Press. 
Ruse, M. (2010). Are God and nature then at strife? Making space for religion in an age of science. Cambridge: Cambridge University Press.

Ruse, M., \& Wilson, E. (1985). The evolution of morality. New Scientist, 1478, 108-128.

Ruse, M., \& Wilson, E. (1986). Moral philosophy as applied science. Philosophy, 61, 173-192.

Sidgwick, H. (1874). The methods of ethics. London: Macmillan.

Singer, P. (2005). Ethics and intuitions. Journal of Ethics, 9, 331-352.

Skyrms, B. (1998). Evolution of the social contract. Cambridge: Cambridge University Press.

Sober, E., \& Wilson, D. (1997). Unto others: The evolution of altruism. Cambridge, MA: Harvard University Press.

Spencer, H. (1851). Social statics, or the conditions essential to human happiness specified and the first of them developed. London: J. Chapman.

Spencer, H. (1857). Progress: Its law and cause. Westminster Review, LXVII, 244267.

Wilson, E. (1984). Biophilia. Cambridge, MA: Harvard University Press.

Wilson, E. (1992). The diversity of life. Cambridge, MA: Harvard University Press.

Wilson, E. (1994). Naturalist. Washington, DC: Island Books.

Wright, R. (1994). The moral animal: Evolutionary psychology and everyday life. 
New York: Pantheon Books. 